„Bohemistyka” 2020, nr 3, ISSN 1642-9893

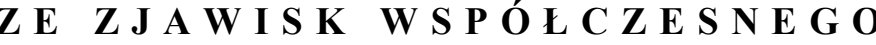 J E Z Y K A C Z E S K I E G O
}

Milan HRDLIČKA

DOI: $10.14746 /$ bo. 2020.3 .9

Univerzita Karlova v Praze

\section{Mongol, nebo Mongolec? ${ }^{1}$}

Keywords: inhabitant names, sufix, usage, variant

Kličová slova: obyvatelské jméno, př́ípona, úzus, varianta

\section{Abstract}

The article describes how to form - with which sufix - inhabitants names (of states, of regions, of cities, etc.) correctly in contemporary Czech, for example how to use the name of inhabitant of Mongolia (Mongolian) correctly: Mongol, or Mongolec?

Obyvatelská jména je možné rozdělit do dvou základních skupin - na pojmenování obyvatel obcí a na názvy občanů států, popř. regionů.

Názvy obyvatel obcí se většinou tvoří ze zavřeného kmene pojmenování obce sufixem -an (Pařiž - Pařižzan). Dochází při tom ke změně předkoncové souhlásky: [h] a [g] se mění v [ž], konsonant [k] alternuje s [č] (Praha-Pražan, Hongkong - Hongkonžan, Hamburk - Hamburčan). Při odvozování se systémově měkčí souhlásky,

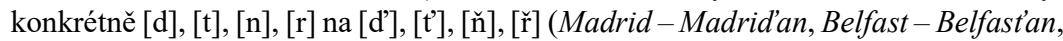
Londýn - Londýńan, Káhira - Káhiřan). Jen zř́́dka se objevuje sufix -ec: Amsterodam-Amsterodamec. Podobné př́ípady potíže nečiní.

Složitější situace nastává jde-li o názvy měst resp. jejich obyvatel málo uživaných, postrádajících v češtině vyhraněnější a ustálenější uzuální formu. V obecné rovině lze jako řešení doporučit opisné vyjádření, které spolehlivě potížím předchází (obyvatel Buenos Aires, obyvatel Rio de Janeira, nikoliv nevhodné ,Buenos Airesan', Rio de Janeiran').

V úvahu připadá i někdy poněkud ošidný pokus o odvozenou podobu obyvatelského jména. Jakým způsobem postupovat kupř̀. v př́ípadě obyvatele Managuy? Bude

1 Tato studie vznikla za podpory projektu Univerzity Karlovy Progres Q10, Jazyk $\mathrm{v}$ proměnách času, místa, kultury. 
náležitý tvar Managuan, nebo Managuec (Managujec)? ${ }^{2}$ Následky takových počinů nemajících solidní oporu ve spisovném či kolokviálním úzu nežrídka vzbuzují pochybnosti, působí rozkolísaně. To je z komunikačního hlediska jistě nežádoucí.

Někdy se setkáváme s konkurencí př́ípon -an a -ák: Pražan x Pražák, Plzeňan x Plzeñák, Hradečan x Hradečák. Snad s výjimkou Vídně (Vídeňan x Vídeñák), ${ }^{3}$ popř. některých slovenských obcí (pod vlivem slovenštiny), ${ }^{4}$ jde o záležitost ryze tuzemskou. Jen sotva si lze představit varianty Řim - Ríman x , Rímák', Mnichov-Mnichovan $\mathrm{x}$, Mnichovák' aj.

Postoj k variantním jménům obyvatel českých a moravských obcí vyjádření není jednoznačný ani jednotný. Rozdíly $\mathrm{v}$ interpretaci se mohou lišit např́č generacemi i regiony. Zatímco vedle neutrálního pojmenování Pražan (pro někoho však až knižnějšího) může působit jeho paralela Pražák (No jo, zase ty Pražáci!) poněkud hanlivým dojmem. ${ }^{5}$ Lexémy jako Plzeñák, Hradečák, Brňák jsou oproti tomu spíše povahy hovorové.

Zajímavou, poněkud opomíjenou, specifickou podmnožinu obyvatelských jmen tvoří substantivizovaná adjektiva typu Kladenští, Pardubičtí. Z hlediska tvaroslovného jde o jména pomnožná, $v$ daném významu nemají singulár. $Z$ perspektivy slovotvorné se jeví jako neproblémová. Nápadný je jejich hojný výskyt v nominativu. Př́iznačným rysem je skutečnost, že zpravidla neoznačují obyvatele dotyčné obce obecně, nýbrž pojmenovávají pouze jejich určitou část, a sice organizované skupiny lidí (sportovní kluby či oddíly, pracovní kolektivy apod.).

Podstatně pestřejší a složitějš́ je tvoření pojmenování př́islušníků státních útvarů a jejich regionů. Nejčastěji si konkurují pojmenování s nulovým sufixem (Švéd, Ir, Bavor), s prííponou -an (Čínan, Island'an, Korsičan) a -ec (Korejec, Portugalec, Bretonec), popř. se sufixem rozšířeným (Barmánec, ${ }^{6}$ Kubánec, Peruánec). Situace je dosti nepřehledná, spíše než o transparentním systému lze hovořit o různých tendencích s variantními podobami jmen.

Od poloviny států Evropy i jiných zemí se tvoří jména obyvatel bez př́ípony, viz Ind, Uzbek, Tádžik, Armén, Kazach aj. Jen minimum lexémů má př́íponu -ák: Polák, Slovák; zvláštní postavení zaujímá lexém Čech. Nejčastějšími sufixy, zhruba s obdo-

${ }^{2}$ Podobné rozpaky mohou vyvolávat i názvy obyvatel států. Štícha a kol. (2011, s. 247) uvádí jako doklad Lotyšsko. Zaznamenány jsou podoby Lotyšs, ale také Lotyšec či Lotyšan.

${ }^{3}$ Tato verze se jako neutrální užívá na Moravě: Vídeñáci dojeli.

${ }^{4}$ Štícha a kol. (2011, s. 238) uvádí: „Na základě rozlišení mezi slovy Žiliňan (každý obyvatel města, včetně přistěhovalců) a Žilinec (původní, autochtonní obyvatel s váženým postavením a profesí) spoluzaložil v roce 1991 Sbor Žilinců a stal se jeho předsedou."

${ }^{5}$ Srov. dublety Rus x Rusák, Žid x Žid’ák, Rakušan x Rakušák (tato varianta je na Moravě mnohdy pocitována jako neutrální).

${ }^{6}$ Nikoliv tedy Barman, jak bylo možné dříve slýchat. Barma se však nyní jmenuje Myanmar, takže tato potíž odpadá. Jindy hrají roli sémantické rozdíly: Bosňan je označení pro všechny obyvatele Bosny, kdežto Bosňák je př́slušník tamní muslimské komunity. bou četností výskytu, jsou -an a -ec. Z důvodu neexistence jednoznačných derivačních pravidel je mnohdy volba fakultativní, bývá záležitostí jazykového citu. Jedna z dublet v řečové obvykle výrazněji převažuje: Brazilec je užívanější než Brazilan, Moldavan dominuje nad Moldavcem ${ }^{8}$ (daný tvar evokuje pojmenování Moravec, zastaralé označení Moravana).

Pro ilustraci uvádíme vybrané zásady odvozování pojmenování př́islušníků národů. Př́ípona - an se užívá, je-li zakončení státu na $-k,-s,-s,-t,-d$ (Mosambičan, Laosan, Kuvajt’an aj.), dále na samohlásku - $a$, které předchází konsonant $[\mathrm{d}],[\mathrm{t}],[\mathrm{k}],[\mathrm{t}],[\mathrm{w}]$, [ž] (Kanad'an, Kostaričan, Kambodžan; vedle Aljašan existuje podoba Aljaščan) a na samohlásku -e, -y, -o (Zimbabwan, Seychelan, Konžan). Sufix -ec se uplatňuje u zemí zakončených na - $m,-l$ (Surinamec, Senegalec, Izraelec), ${ }^{9} \mathrm{~s}$ koncovou samohláskou -a, jíž předchází [v], [e], [u] (Litevec, Eritrejec, Nikaragujec), s vyslovovanou souhláskou -j, -je (Paraguayec, Uruguayec, Libyjec).

Závěrem prezentujeme pravidlo, na němž lze náročně ukázat nesnadnost, rozkolísanost a uzuální povahu tvoření obyvatelských jmen. Jména př́slušníků národů se tvoří bez př́ípony od států zakončených na -sko. Máme tedy formy typu Mad'ar, Švýcar, Bulhar - a systémově rovněž Mongol. Ovšem pozor: v případě týchž zemí je mimo jiné možné také užití prípony -ec, odtud kromě jiného podoby Estonec, Lichtenštejnec, Nizozemec ... A v neposlední řadě Mongolec.

Tvoření obyvatelských jmen je kapitolou zajímavou, nicméně dosti komplikovanou. $\mathrm{V}$ př́ípadě potřeby je proto jistější oveř̌it náležitou formu ve slovníku, resp. v normativní jazykové príručce a nespoléhat pouze na jazykový cit.

\section{Literatura}

Š tíc h a F. a kol., 2011, Kapitoly z české gramatiky, Praha: Academia.

${ }^{7}$ Zvláštní skupinu tvoří kolokviální podoby, kupř. Amík (Američan), Anglán (Angličan), Frantík (Francouz), moravské Taloš, zastaralé Talián (Ital), někdy i povahy hanlivé: Ukroš, Úkáčko (Ukrajinec), rákosník (Vietnamec), Němčour, skopčák (Němec) atd.

${ }^{8}$ Někdy jsme svědky rozdílů dobových, srov. bývalé označení Charvát, Marokánec a dnešní Chorvat, Maročan.

${ }^{9}$ Nelze zaměňovat s označením izraelita (člen židovské církve) 